\title{
Long-term influence of maritime access works on the distribution of cohesive sediments: analysis of historical and recent data from the Belgian nearshore area (southern North Sea)
}

\author{
Michael Fettweis • Jean-Sébastien Houziaux • Isabelle Du Four • Vera Van Lancker • \\ Cecile Baeteman • Mieke Mathys • Dries Van den Eynde • Frederic Francken • \\ Stanislas Wartel
}

Received: 6 January 2009 / Accepted: 29 June 2009/Published online: 4 September 2009

(C) Springer-Verlag 2009

\begin{abstract}
Long-term changes in the cohesive sediment distribution of the Belgian-Dutch nearshore zone (southern North Sea) are related to human activities (port construction, deepening of navigation channels, disposal of dredged sediments) and to natural variability, due to tides and meteorological effects. Results are based on the combined
\end{abstract}

M. Fettweis $(\bowtie) \cdot$ D. Van den Eynde $\cdot$ F. Francken $\cdot$ S. Wartel

Royal Belgian Institute for Natural Science (RBINS),

Management Unit of the North Sea Mathematical

Models (MUMM),

Gulledelle 100,

Brussels 1200, Belgium

e-mail: m.fettweis@mumm.ac.be

J.-S. Houziaux

Royal Belgian Institute for Natural Science (RBINS),

Invertebrates Department,

rue Vautier 29,

Brussels 1000, Belgium

I. Du Four · V. Van Lancker · M. Mathys

Renard Centre of Marine Geology (RCMG), Ghent University,

Krijgslaan 281, S8,

Ghent 9000, Belgium

C. Baeteman

Royal Belgian Institute for Natural Science (RBINS),

Geological Survey of Belgium,

Jennerstraat 13,

Brussels 1000, Belgium

Present Address:

V. Van Lancker

Royal Belgian Institute for Natural Science (RBINS),

Management Unit of the North Sea Mathematical

Models (MUMM),

Gulledelle 100,

Brussels 1200, Belgium analyses of recent and historic (100 years ago) sediment sample information and bathymetric maps. Data processing was based mainly on field descriptions of the samples (consolidation, thickness) and on bathymetric maps of 1866-1911. Results indicate that the distribution of fresh mud and suspended sediment has changed during the last 100 years, due mainly to maritime access works. Most of the present deposition of thick layers of fresh mud $(>30 \mathrm{~cm})$ has anthropogenic causes. The results further indicate that erosion of older Holocene mud has increased in recent times and, as a consequence, higher amounts of fine-grained sediments are being released into the southern North Sea today.

\section{Introduction}

Most of the coast of the southern North Sea has had a long history of human impact, due mainly to coastal defence and harbour infrastructure works. The latter are associated with the deepening of navigation channels and harbour entrances, and disposal of dredged material at designated sites. Resource and energy demands have led to the establishment of marine aggregate concession zones and offshore windmill farms, as well as the laying of numerous cables and pipelines. An increasing number of studies have dealt with this growing influence of human activities on southern North Sea dynamics, many focusing on physical impacts (e.g. Delafontaine and Flemming 2000; Mai and Bartholomä 2000; Flemming 2002; Jaffe et al. 2007; Van Lancker et al. 2007; Du Four and Van Lancker 2008). However, reference situations are rarely available in the marine environment and, therefore, true impacts are difficult to be assessed unambig- 
uously (e.g. Zviely et al. 2009). In addition, the natural variability of, e.g. sediment fluctuations is high in these dynamic settings; as such, the human footprint is difficult to identify.

When human activities occur in habitats characterised by cohesive seabed sediments, resuspension of material can result in high concentrations of suspended particulate matter (SPM), which can spread over large areas. Alterations of the cohesive sediment distribution are to be expected because infrastructure works, together with dredging and the disposal of sediments, often result in hydrodynamic conditions which are not in equilibrium with the present-day bathymetry. However, the manner in which the system reacts to large engineering works needs to be understood to ensure cost-effective operations at sea, to better gauge the human footprint, and to develop environmental policies aiming at a more sustainable management of the marine environment.

This paper presents a case study where historic (100 years old) and recent sediment and bathymetric data have been combined to evaluate the impact of maritime access works on the distribution of cohesive sediments along the Belgian-Dutch coast. The aim of the study is to determine to what extent the distribution of cohesive sediments and the transport of SPM may have changed due to increasing anthropogenic activities during the last century. The study area is crucial to the understanding of SPM transport in the southern North Sea, since SPM entering the North Sea through the Dover Strait is first concentrated in front of the Belgian-Dutch coast, before being transported further towards the northeast (Fettweis et al. 2007a). In this paper, long-term human-induced effects are assessed, based on qualitative sediment descriptions of historic and recent samples, in combination with results of morphological evolution. The cohesive sediment distribution of 100 years ago has been reconstructed to reflect the situation before major human impacts took place. The study is one of very few (e.g. Hamilton 1999) where qualitative and quantitative sediment descriptions of historic and recent samples have been used to identify differences between the actual situation and a previous one.

\section{Regional setting}

Hydrography and suspended sediments

The study area is situated in the southern North Sea. Water depths vary between 0-20 m below MLLWS (mean lowest low water spring tide; Fig. 1). The mean tidal range at Zeebrugge (Fig. 1) is 4.3 and $2.8 \mathrm{~m}$ at spring and neap tide respectively. The tidal current ellipses are elongated in the nearshore area and become gradually more semicircular towards the offshore. This means that maximum current velocities are higher and minima lower in the nearshore area than further offshore. The current velocities near Zeebrugge (nearshore) vary from $0.2-1.5 \mathrm{~m} \mathrm{~s}^{-1}$ during spring tide and $0.2-0.6 \mathrm{~m} \mathrm{~s}^{-1}$ during neap tide (see operational model results at www.mumm.ac.be). Winds blow dominantly from the southwest but the highest waves occur during north-westerly winds.

SPM forms a turbidity maximum between Oostende and the mouth of the Westerschelde estuary. English Channel water from the southwest, and the Schelde and Rhine rivers influence the salinity of Belgian waters (Lacroix et al. 2004). The strong tidal currents and the low freshwater discharge of the Schelde (yearly average of $100 \mathrm{~m}^{3} \mathrm{~s}^{-1}$ ) result in a well-mixed water column. Measurements indicate variations in SPM concentration in the nearshore area of 20-70 $\mathrm{mg} \mathrm{l}^{-1}$ and reaching 100->1,000 $\mathrm{mg} \mathrm{l}^{-1}$; lower values $\left(<10 \mathrm{mg} \mathrm{l}^{-1}\right)$ occur in the offshore (Fettweis et al. 2007a). The most important sources of SPM are the French rivers discharging into the English Channel, coastal erosion of the Cretaceous cliffs at Cap Griz-Nez and Cap BlancNez (France), and erosion of nearshore Holocene mud deposits. The Westerschelde estuary is not considered to be a significant source of mud (Van Maldegem et al. 1993).

\section{Geology}

The cohesive sediments in the nearshore zone of the study area consist of Eocene clay (Maréchal 1993), Holocene consolidated mud, freshly deposited mud and SPM. The freshly deposited muds generally occur as thin $(<2 \mathrm{~cm})$ fluffy layers or, locally, as increasingly more consolidated, thicker packages $( \pm 0.2-0.5 \mathrm{~m}$ thick $)$. The Holocene deposits consist of semi-consolidated mud, intercalated with more sandy layers; they are often covered with thin (a few $\mathrm{cm}$ thick) ephemeral sand layers or fluffy layers. In offshore swales, the thickness of the Quaternary cover is locally less than $2.5 \mathrm{~m}$; in these areas, Eocene outcrops (clay) are to be expected (Le Bot et al. 2003; see Fig. 2).

This complexity is strongly related to the development of the coastal plain during the Holocene (Fig. 3). The thickness of Holocene deposits (excluding aeolian deposits) along the present coastline varies between $\pm 25 \mathrm{~m}$ in the west to not more than $10 \mathrm{~m}$ in the east, except for young Holocene sand-filled tidal channels. The thickness and width of these deposits are defined by the morphology of the pre-transgressive surface, i.e. the top of the Pleistocene deposits, and the occurrence of palaeovalleys (Baeteman 1999; Beets and van der Spek 2000). The Holocene sequence in the coastal plain consists mainly of alternations of intertidal mud and peat beds. The uppermost intercalated peat bed developed ca. 6,300-5,500 cal. years B.P. in the landward part of the plain, and ca. 4,700 cal. years B.P. in 
Fig. 1 Modern bathymetric map of the Belgian nearshore area between the French border (left) and the mouth of the Westerschelde, showing the three major disposal grounds of dredged material (shaded ovals $\mathrm{B} \& \mathrm{~W}-\mathrm{S} 1, \mathrm{~B} \& \mathrm{~W}-\mathrm{ZO}, \mathrm{B} \& \mathrm{~W}-\mathrm{O})$ in Belgium. $B C S$ Belgian Continental Shelf

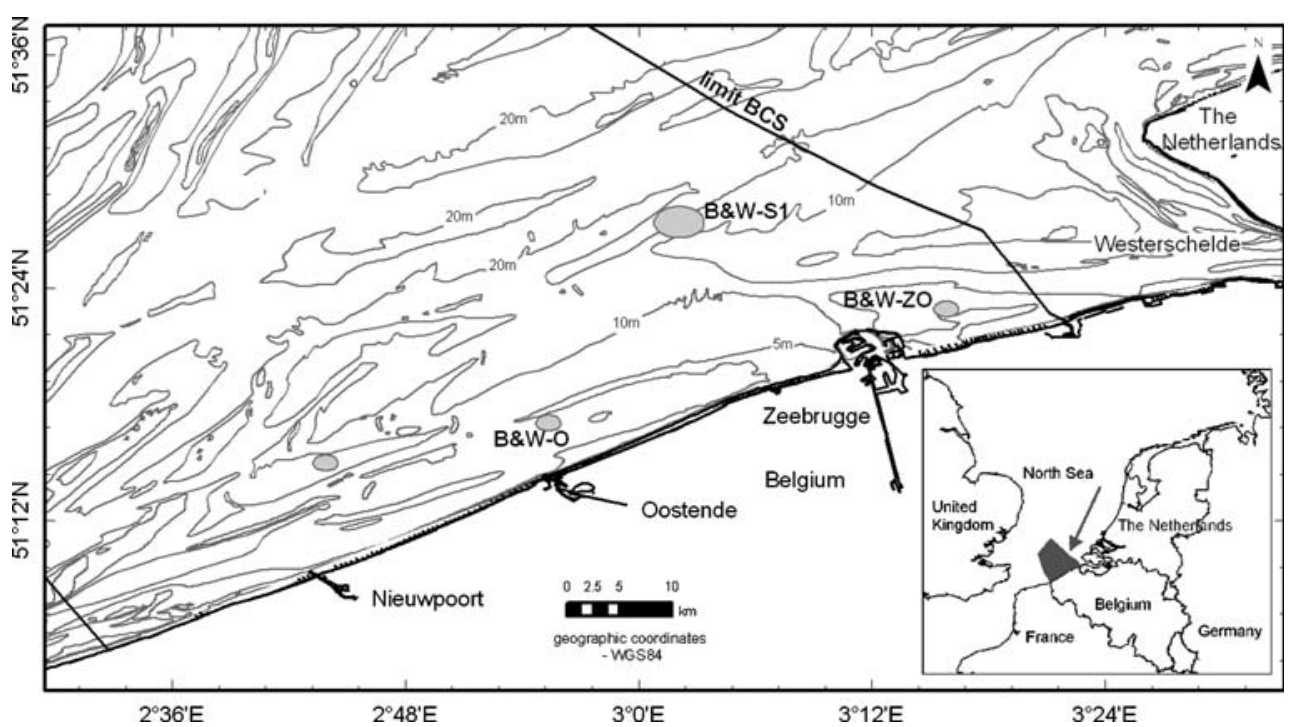

erosion coincides with the period of Roman occupation between 1,950-1,750 cal. years B.P. (Baeteman 2008).

\section{Human impact}

The construction of the port of Zeebrugge (Fig. 1) in the 20th century, including the dredging or deepening of navigation channels and the associated disposal of sediments, represents the most conspicuous anthropogenic
Fig. 2 Extension of Holocene mud on the Belgian Continental Shelf, based on vibrocores, and the areas where the Quaternary cover is less than $2.5 \mathrm{~m}$ thick. Tertiary clays outcrop in the navigation channel towards the Westerschelde (far right)

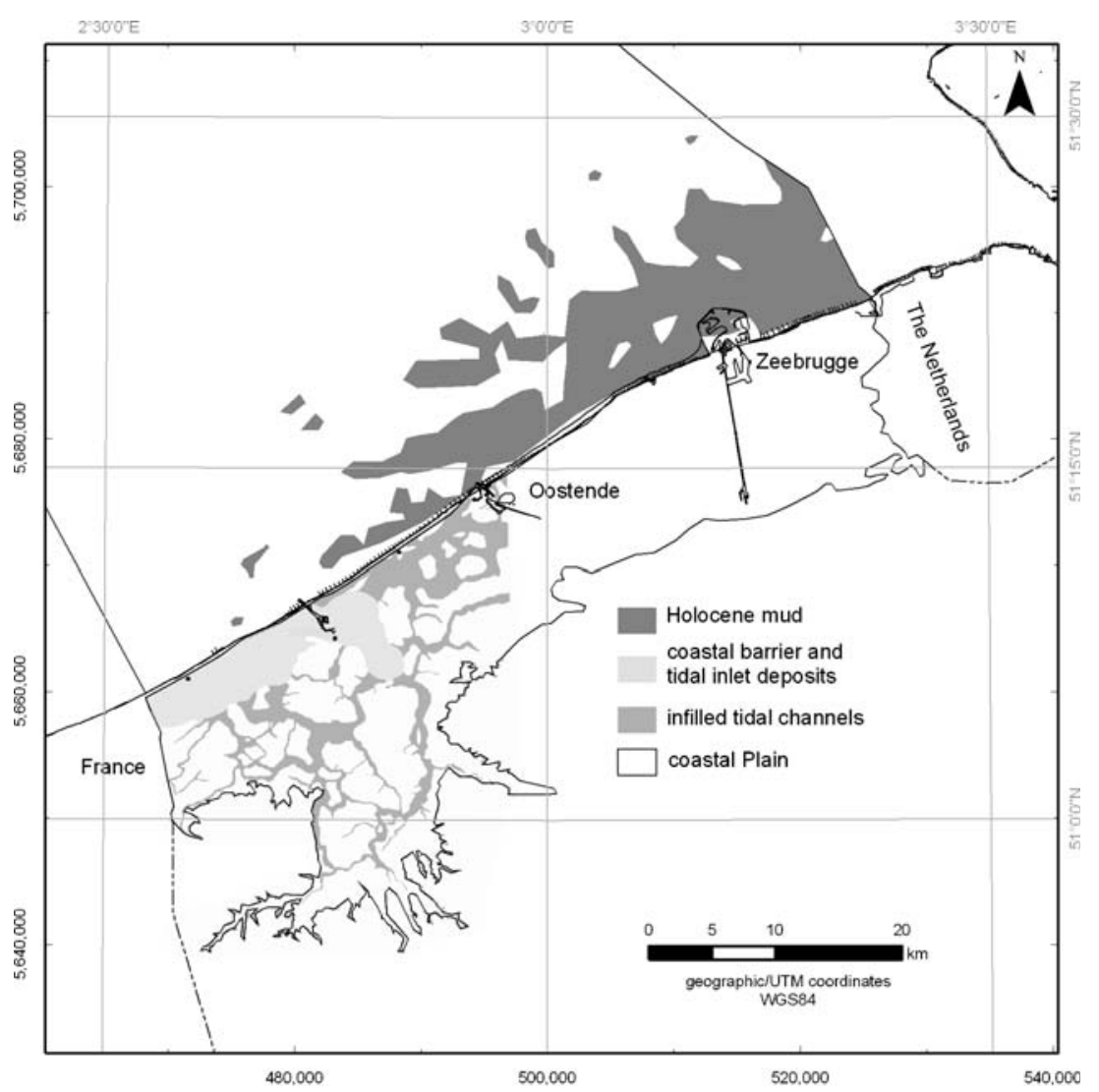


Fig. 3 Map of Holocene deposits on the Belgian coastal plain (based on Baeteman 2008), complemented with data from the nearshore zone. Only the Holocene deposits of the western coastal plain are shown in detail; no information is available on the eastern plain

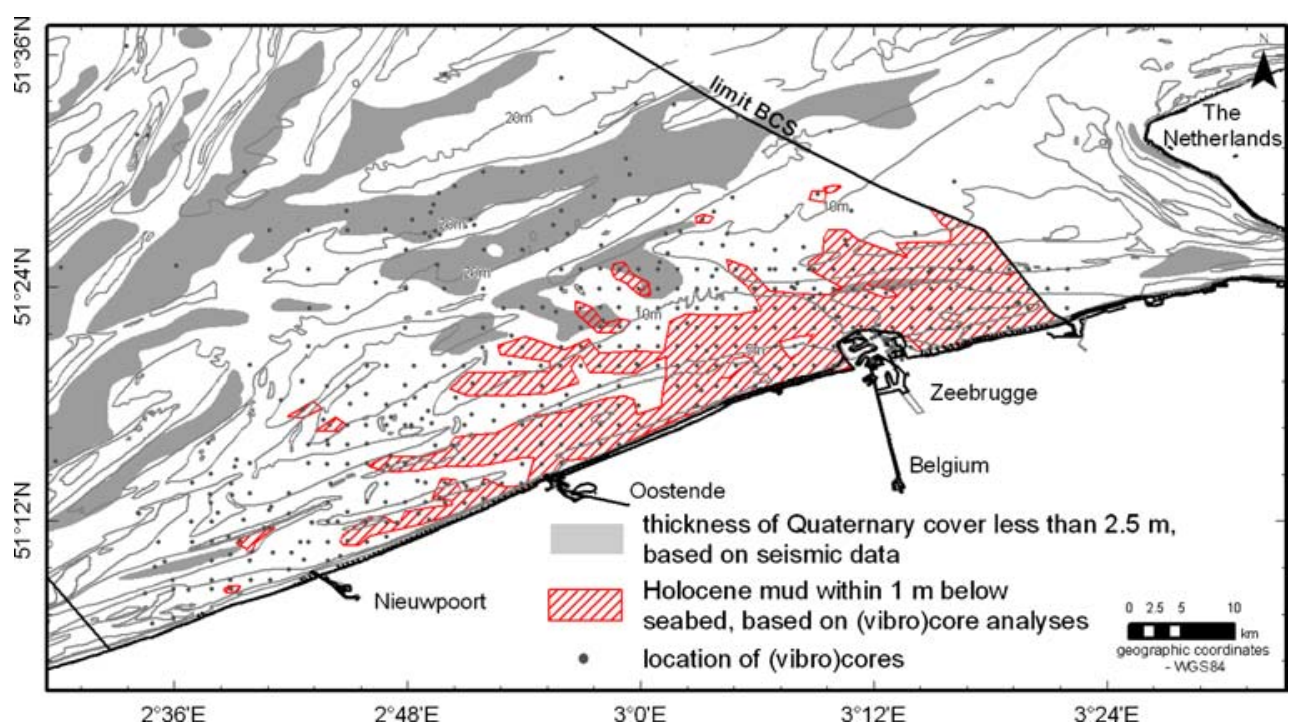

impact in the study area. The construction of the port was carried out between 1899 and 1903; in those times, the breakwater had a length of $1.7 \mathrm{~km}$ and a maximum distance from the coast of $1.1 \mathrm{~km}$. A navigation channel towards the port was dredged in 1903 through a sandbank (Van Mierlo 1908). Since then, many modifications have been carried out in order to deepen and widen the access channels and, finally, to extend the outer port. Significant expansion works were carried out between 1980 and 1985, with the construction of two 4-km-long, parallel breakwaters extending about $3 \mathrm{~km}$ out to sea. Today, the outer port has a depth of up to $16 \mathrm{~m}$ below MLLWS and a connection towards the open sea of $14 \mathrm{~m}$ below MLLWS; the port and the channels are thus substantially deeper than the nearshore area where water depths are generally less than $10 \mathrm{~m}$ below MLLWS.

To conserve the maritime access to the coastal harbours and to the Schelde estuary, continuous dredging is needed (Lauwaert et al. 2008). Maintenance dredging today amounts to about 8.6 millions tons of dry matter yearly and capital (major) dredging to 2.8 million tons of dry matter (averages over 1997-2006). More than 70\% of the dredged sediment consists of silt and clay. The main disposal grounds of dredged material are sites B\&W-S1 (54\%), B\&W-ZO (32\%) and B\&W-O (14\%; cf. Fig. 1).

\section{Materials and methods}

Mapping of historic and recent cohesive sediments

The distribution of cohesive sediments in the study area have been mapped extensively over the past 100 years or so (Stessels 1866; Van Mierlo 1899; Bastin 1974; Missiaen et al. 2002; Van Lancker et al. 2007), based on in situ sampling and, in recent times, increasingly by remote geophysical methods (natural radioactivity, seismics, multibeam echo-sounder, side scan sonar). To compare historic and recent sediment distributions, it was decided to base the mapping mainly on detailed field descriptions of sediment samples in combination with bathymetric maps. Based on field descriptions, four characteristic features of cohesive sediment distribution were identified which occur in both the historic and recent datasets: clay pebbles, stiff mud, soft mud and liquid mud. These sediment types are related to consolidation and/or erosion/deposition processes and can, therefore, provide an estimate of the relative age of the sediments.

The recent sediment samples were collected from onboard the R/V Belgica between 2000 and 2004 using a van Veen grab and a Reineck box corer. The samples were analysed after removal of the organic and carbonate fractions. Grain-size analysis was carried out by means of wet sieving and a Sedigraph for the fraction $<75 \mu \mathrm{m}$. The data were used to map the mud content (fraction $<63 \mu \mathrm{m}$ ) of the Belgian nearshore area. Bulk density measurements based on gamma ray densitometry were carried out on selected box-core samples (see Fettweis et al. 2007b). Following the Coastal Engineering Manual (2002) terminology, these measurements enabled classifying the cohesive sediment samples as "soft to semi-consolidated" (wet bulk density $\rho_{\mathrm{b}}=1,500-1,800 \mathrm{~kg} \mathrm{~m}^{-3}$ ), "freshly deposited to very soft consolidated" $\left(\rho_{\mathrm{b}}=1,300-1,500 \mathrm{~kg} \mathrm{~m}^{-3}\right)$ and "fluid mud" ( $\left.\rho_{\mathrm{b}}= \pm 1,100-1,200 \mathrm{~kg} \mathrm{~m}^{-3}\right)$.

The historical sediment distribution was mapped based on sediment samples collected by G. Gilson in the first decade of the 20th century. In order to understand the environmental parameters influencing the distribution of marine invertebrates, Gilson, a marine biologist, carried out extensive standardised sediment sampling campaigns (Gilson 1900; Houziaux et al. 2008). The archived inventory of Gilson's sediment samples contains a list of 2,979 sampling 
events between 1899 and 1939, of which 90\% occurred before 1911. Gilson's cup-shaped instrument (ground collector) was able to sample the upper 10-20 cm of soft bottoms, and enabled a good conservation of sediment layers in the samples (Gilson 1901; Van Loen et al. 2002). Unfortunately, most of the samples have been lost. However, detailed field descriptions of the sediment samples are still available. These include sediment parameters such as mud content, sand grain size, shell content and gravel content. For the nearshore area, 1,956 of these historic sediment samples are considered valid in terms of sedimentological information content and geo-referencing accuracy. The level of detail of the sample descriptions is high and enabled construction of a relative mud content scale in which "pure mud" is considered to correspond to $100 \%$ mud content. Gilson often indicated additional information on mud appearance, such as "in pieces" or "in lumps", "hard", "liquid", "grey", "black" or "superficial", providing clues to relative age, consolidation and origin. Occasionally, additional indications on bottom hardness, as recorded with a depth sounding weight, are given. This information has been taken into account to identify areas with soft to semi-consolidated cohesive sediments and to perform comparisons with contemporary mud samples. Only positive indications are considered as valid data because it is not certain that such features were always appropriately recorded and, thus, their absence could also be due to misreporting.

The bathymetric maps of Stessels (1866) and Urbain (1909) were used to link the occurrence of cohesive sediments to morphological changes. If the historic cohesive sediment sample was located in an area where depths decreased, then the mud was considered to have been deposited recently (maximum 35 years). If the sample was located in an eroded or stable area, then the mud was considered to be old (Eocene, Holocene or subrecent). However, fresh mud may occur in all areas as a thin surface layer related to tidally induced deposition (e.g. spring-neap variation), such as described in the metadata.

\section{Results}

Historical cohesive sediment distribution

The approach described above enabled construction of a coherent historic map of relative mud distribution along the Belgian coast and the mouth of the Westerschelde estuary (Fig. 4a). The results show high relative mud contents between Oostende and Zeebrugge. This area became shallower between 1866 and 1911 (Stessels 1866; Urbain 1909), indicating sediment accumulation during that period. Accumulation is observed in a 5-km-wide, coast-parallel mud belt (Fig. 5). The highest accumulation $( \pm 3 \mathrm{~m})$ occurred between Oostende and Zeebrugge, an area corresponding to high relative mud contents at that time (Fig. 4a). Areas where the seafloor has deepened (>1 m) are often artificial and situated in navigation channels. These areas are sinks for fine-grained sediments. Further offshore, deepening is probably natural and must be related to erosional processes. Thus, the offshore muds most probably coincide with outcrops of older mud (Holocene or Tertiary).

\section{Modern cohesive sediment distribution}

Figure $4 \mathrm{~b}$ shows the mud content and the distribution of the four major cohesive sediment facies emerging from the sample descriptions, wet bulk density measurements and grain-size analyses. The classification is based on the bulk densities of pure cohesive sediments. This should be used as a first indicator only because small amounts of sand, which often occur in the mud, may increase the bulk density. The four main facies are:

- mud pebbles (Fig. 6) occurring in a sand matrix or on top of mud layers, indicating erosion (naturally or due to capital dredging works) and transport of clays and consolidated mud layers;

- soft to semi-consolidated cohesive sediments, considered to be largely of Holocene age and possibly including very recent sediments. Based solely on the degree of consolidation, it was not always possible to clearly identify the relative age of the sediment. Generally, the Holocene mud has an irregular density profile, reflecting an alternation of mud and thin sand layers. This layered structure is typical for alternations of storm and calm weather periods and/or spring-neap tidal cycles. Other types of consolidated mud are sticky, without any clear layering visible; these are here called "modern mud". Radiometric measurements indicate an age of more than 50 years (Fettweis et al. 2007b).

- freshly deposited to very soft cohesive sediments, possibly indicating very recent deposits of thicker mud layers or rewetted older and more consolidated mud. Freshly deposited muds are considered as recent mud deposits related to human activities; they occur in ports, navigation channels and other humanimpact areas such as the old disposal ground of dredged material near Oostende (B\&W-O; Fig. 1). The deposits have a layered structure, resulting from alternating storm and calm weather deposition and/or spring-neap tidal cycles. Erosion of these sediments is probably only possible during storm events with large wave heights.

- fluid mud, flowing through fingers and occurring as thin surface layers (fluffy layers a few $\mathrm{cm}$ thick) or 
Fig. 4 Cohesive sediment facies, mud content in the Belgian-Dutch nearshore zone: a historic (Gilson 1900) and b recent. Recent mud content is obtained from grain-size analyses, whereas historic mud content is derived from Gilson's detailed field descriptions and is reported in terms of a relative scale. The bathymetry in both figures is from 2003
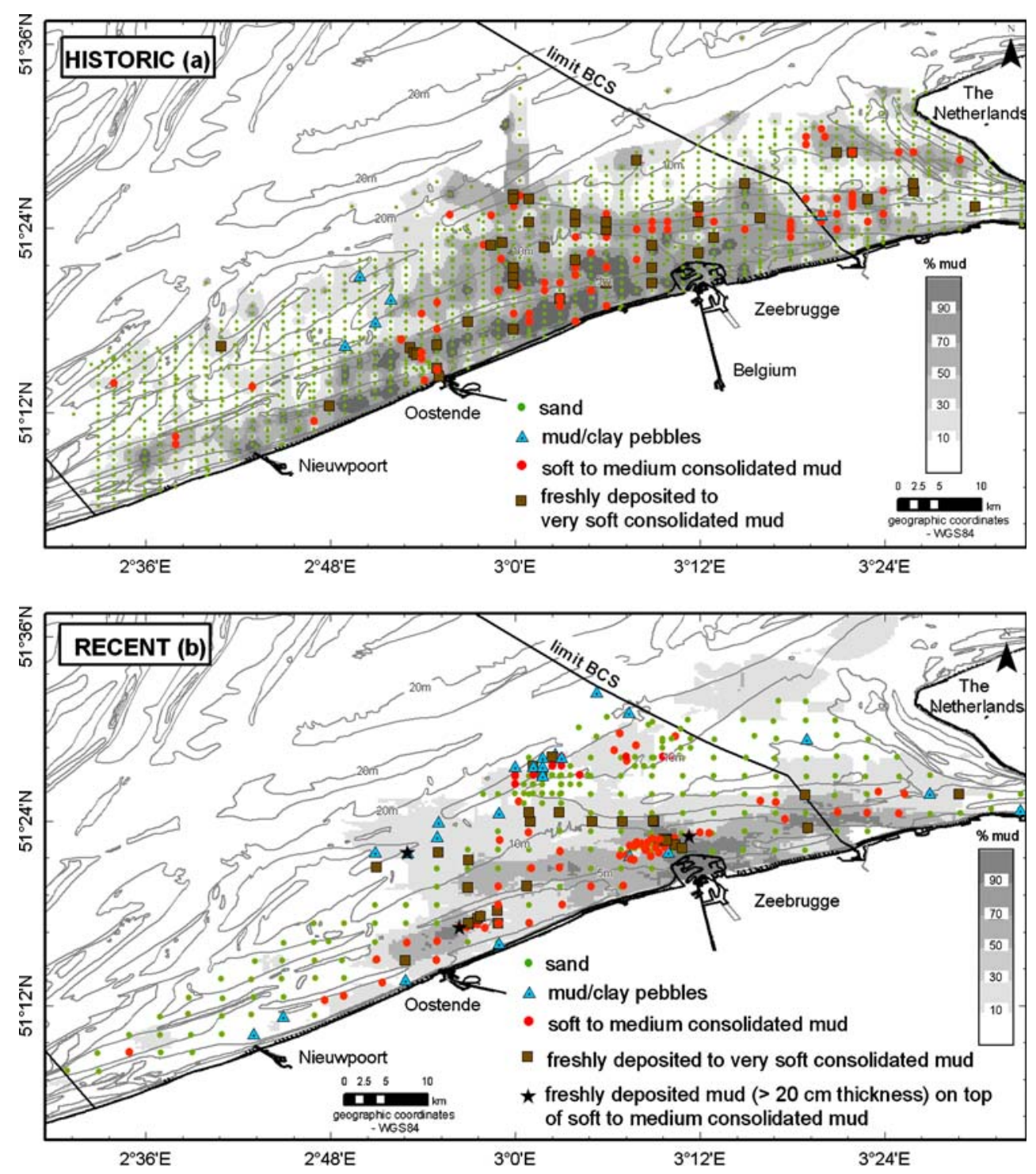

thicker layers in ports and navigation channels. Fluffy layers are continuously being resuspended and newly formed during spring-neap tidal cycles.

\section{Discussion}

The construction and extension of the port of Zeebrugge and its connections to the open sea, the disposal of dredge spoil, and the morphological evolution induced by these operations have had, and still are having, a substantial influence on the distribution of fine-grained sediment in the study area. Generally, the historic relative mud content corresponds well to the modern quantitative mud content (Fig. 4a, b). However, some striking differences are noted, in particular higher present-day (relative) mud contents in the nearshore area between Oostende and Zeebrugge. The comparison between the historic and recent data also shows that the distributions of freshly deposited to very soft consolidated mud and of clay pebbles have changed. Possible explanations are discussed below in terms of natural or human-induced morphological changes, dredging and sediment disposal, increased erosion of clayey sediments, and changes in storminess and sea level.

Deposition of fine-grained sediments

From a combination of the relative mud contents derived from Gilson's meta-information (Fig. 4a) and morphological changes between 1866 and 1911 (Fig. 5), it can be seen that mud deposits formerly occupied a narrow belt aligned parallel to the coastline. Comparing the bathymetric maps of 1866/1911 with the observations of Van Mierlo (1908) suggests that these changes started before the construction of the port of Zeebrugge and, thus, are most probably the result of natural morphological evolution. The effect of the 
Fig. 5 Combined long-term trends in mud deposition and seafloor morphology, inferred from detailed visual inspection of bathymetric changes for the period 1866-1911, and from historical sediment sample descriptions (see Fig. 4). The depth isolines are digitised from the bathymetrical map of Stessels (1866)

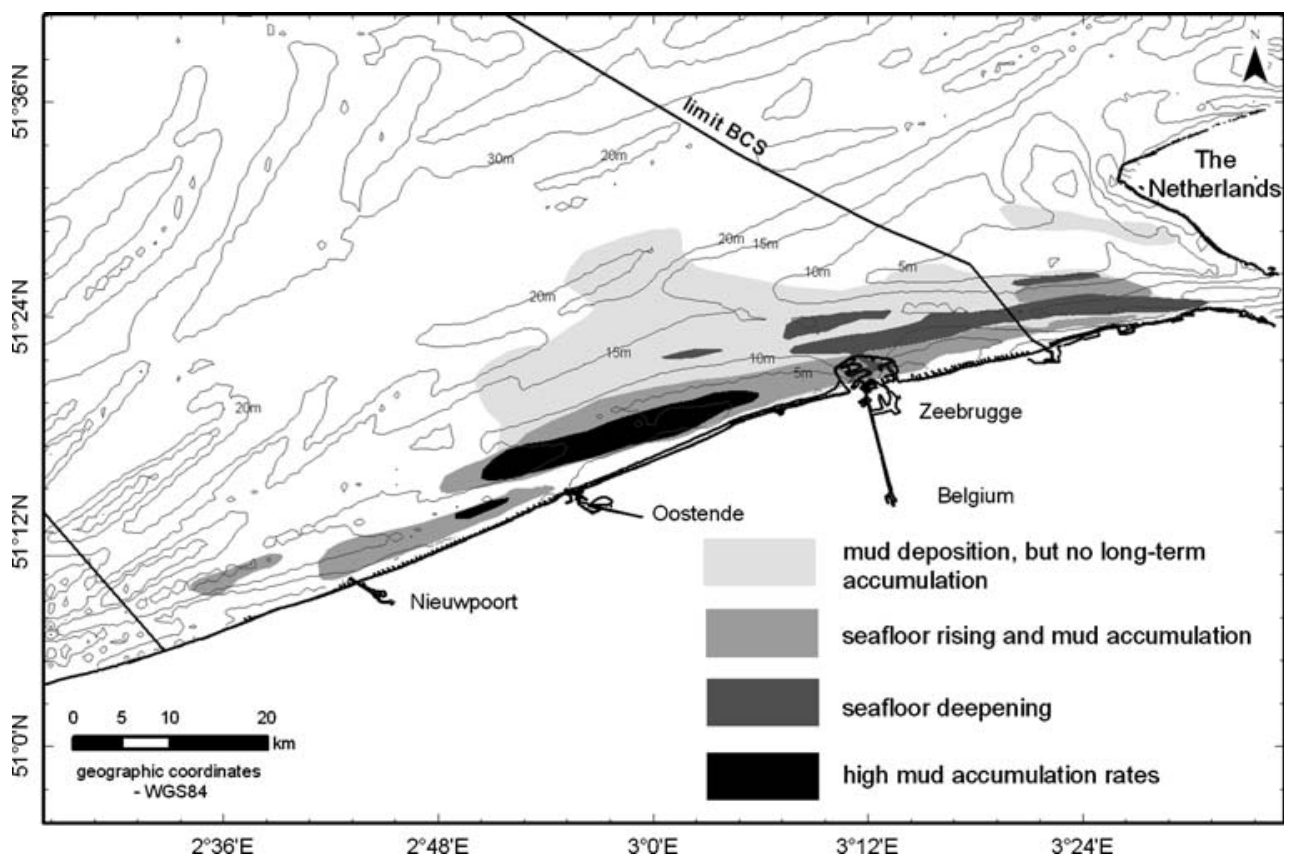

first infrastructure works (1899-1903) has potentially reinforced the natural accretional trends, as predicted by Van Mierlo (1897). At those times, the mud deposits most probably corresponded to the category "freshly deposited to very soft consolidated cohesive sediments" defined in this paper. No information is available on the thickness of these layers, but the fact that Gilson sampled the area on several occasions and found mostly muddy sediments and "very soft" bottoms supports the conclusion that the deposits were prevalent during the considered time interval. If these

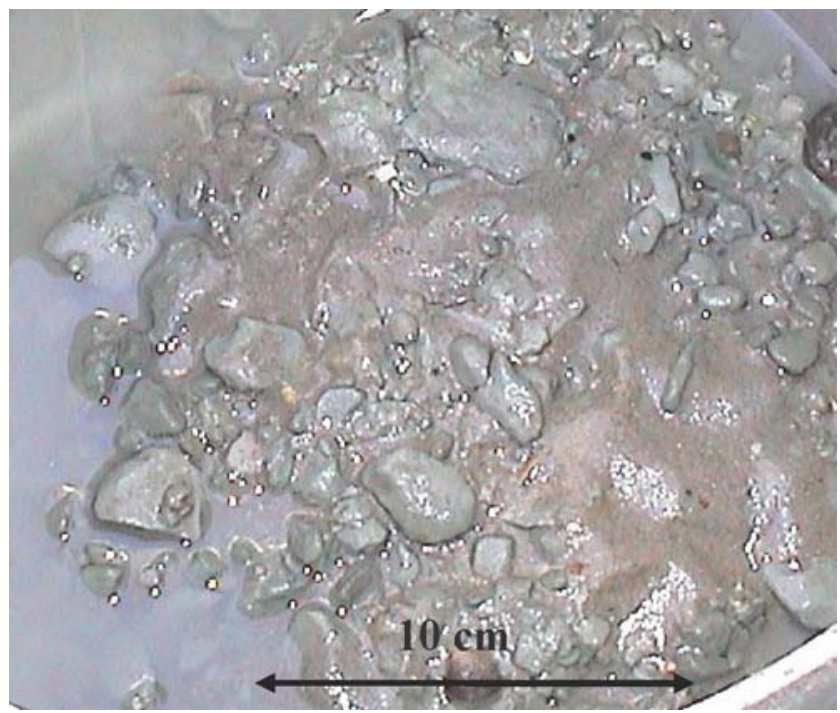

Fig. 6 Box-core sample with mud pebbles on the surface (19 February $\left.2003,51^{\circ} 26.919^{\prime} \mathrm{N}, 3^{\circ} 1.564, \mathrm{E}\right)$; the core was taken near the disposal ground of dredged material $\mathrm{B} \& \mathrm{~W}-\mathrm{S} 1$; the pebbles possibly result from major dredging works sediments still exist today, then they should fit the category "soft to semi-consolidated mud" and, thus, correspond to modern mud. Deposits of modern mud exist in the vicinity of the port of Zeebrugge (Fettweis et al. 2007b).

Today, freshly deposited to very soft consolidated thick mud layers $(>30 \mathrm{~cm})$ are less frequent and concentrated mainly near the old disposal ground of dredged material near Oostende (B\&W-O), in navigation channels, in harbours, and north of Zeebrugge (Fig. 4b). In some samples, this mud is deposited on top of soft to semiconsolidated mud, the latter possibly corresponding to the freshly deposited mud layers at the beginning of the 20th century. The deposition of fresh to very soft consolidated mud near the old disposal ground for dredged material (B\&W-O) started after the 1950 s, as revealed by radiometric measurements (Fettweis et al. 2007b). It was probably induced by the morphological changes caused by the disposal of dredged material (Van Lancker et al. 2007).

Increased erosion of Holocene mud and Tertiary clay

Clay and mud pebbles, a few $\mathrm{cm}$ up to $10 \mathrm{~cm}$ in size and of different rounded shapes, have regularly been found in sandy sediments during the last 100 years (Fig. 4a, b). The rounded shapes indicate that these pebbles have been transported by rolling. Flattened shapes may indicate that they have been eroded from layered Holocene mud. Such pebbles are recorded more frequently today, despite the lower sampling resolution. The higher frequency of clay and mud pebble occurrence in the vicinity of the disposal grounds is most probably linked to the disposal of sediments from capital dredging works (Du Four and Van 
Lancker 2008). Tertiary clays and Holocene muds outcrop in the navigation channels towards the Westerschelde and the port of Zeebrugge (Fig. 2). Elsewhere, mud pebbles have been observed regularly in sandy matrices; these could indicate erosion of Holocene mud. The freshly deposited to soft consolidated mud layers recorded in the nearshore area at the beginning of the 20th century have in many cases disappeared in recent times, except for specific locations related to human activities. Due to the deepening works, Holocene mud deposits more frequently outcrop today. Erosion of soft to semi-consolidated cohesive sediments can occur when sand moves over the top of the cohesive substrate, and through failure of cohesive sediment beds along sandy layers due to wave action (Silva-Jacinto and Le Hir 2001).

Effects of dredging and disposal of sediments

The port of Zeebrugge and its connection to the open sea, as well as the navigation channels towards the Westerschelde estuary, are efficient sinks for cohesive sediments. Comparison between the SPM transport entering and leaving the Belgian Continental Shelf and the quantities dredged and disposed at sea shows that an important part of the SPM is involved in the dredging/disposal cycle (Fettweis and Van den Eynde 2003). The disposal of finegrained sediment temporarily increases SPM concentrations in the water column (Van den Eynde and Fettweis 2006). As a consequence, the high turbidity area has shifted further offshore because SPM concentration near the dredging sites has decreased due to deposition, whereas it has increased in the vicinity of the disposal grounds.

Storminess and sea-level rise

Variations in the frequency of storms and in sea level are important controlling factors in the distribution of cohesive sediments and SPM. The WASA Group (1998) reported that the storm and wave climate in most of the North Sea has undergone changes on a decadal timescale, probably related to variations in the North Atlantic Oscillation Index with periods of 17, 7.7 and 2.4 years (Loewe and Koslowski 1994). Smits et al. (2005) and Weisse et al. (2005) report that variations in storminess have occurred during the last 50 years in the southern North Sea. The intensity of the storm and wave climate in the 1990s seems comparable to that observed at the beginning of the 20th century (WASA Group 1998; Dawson et al. 2002). However, regardless of the decadal change in storminess, no statistical long-term trends ( $>100$ years) have been found for the German Bight (de Jong et al. 1999) or the Belgian part of the North Sea (Van den Eynde et al. 2008). The variation of meteorological conditions can therefore not explain the observed historical changes in cohesive sediment distribution.

Until the 1990s, a mean sea-level rise of about $1.4 \mathrm{~mm}$ year $^{-1}$ has been observed in Oostende (Van Cauwenberghe 1999). From tide-gauge data at Oostende, Ozer et al. (2008) surmised that an increase in the rate of sea-level rise can be observed since 1992, reaching a value of about $4.4 \mathrm{~mm} \mathrm{year}^{-1}$. The latter value is close to the global average rate of $4.0 \mathrm{~mm}^{-1} \mathrm{yr}^{-1}$ for the period January 1993 to December 2002, as extracted from the data of several tide gauges by Holgate and Woodworth (2004), and the value of $3 \mathrm{~mm}$ year $^{-1}$ recorded since 1993 in satellite altimetry data (Bindoff et al. 2007). Based on these findings it is argued that, in 1900 in our study area, the sea level was about $18 \mathrm{~cm}$ lower than in 2003, a value which is too low to expect a significant influence on cohesive sediment or SPM distribution by sea-level rise.

\section{Conclusions}

This paper shows that historical data can provide reliable baseline information for the assessment of long-term human-induced changes in the marine environment. In the Belgian nearshore area (southern North Sea), layers of fresh to softly consolidated mud $(>30 \mathrm{~cm})$ reconstructed for the beginning of the 20th century were the result of natural morphological processes. Today, layers of fresh mud are concentrated in areas with high human impact and are not found in the remainder of the nearshore area. The data also indicate that more Holocene mud probably outcrops today than at the beginning of the 20th century and that, as a consequence, erosion of these layers is more prominent today. The Zeebrugge port extension and associated works have thus in all likelihood increased the amount of finegrained sediment released into the North Sea, a process ongoing today.

Acknowledgements This study was funded partly by the Belgian Science Policy projects MOCHA (EV35), HINDERS (EV45) and QUEST4D (SD/NS/06A) and partly by the Maritime Access Division of the Ministry of the Flemish Community, within the framework of the MOMO project. We gratefully acknowledge the reviewers for helpful criticism and valuable suggestions.

\section{References}

Baeteman C (1999) The Holocene depositional history of the IJzer palaeovalley (Western Belgian coastal plain) with reference to the factors controlling the formation of intercalated peat beds. In: Baeteman C (ed) Quaternary of Belgium: new perspectives. Geol Belg 2:39-72

Baeteman C (2008) Radiocarbon-dated sediment sequences from the Belgian coastal plain: testing the hypothesis of fluctuating or 
smooth late-Holocene relative sea-level rise. Holocene 18 (8): 1219-1228

Bastin A (1974) Regionale sedimentologie en morfologie van de zuidelijke Noordzee en het Schelde estuarium. PhD Thesis, Geography-Geology Department, Catholic University of Leuven, Belgium

Beets JD, van der Spek AJF (2000) The Holocene evolution of the barrier and the back-barrier basins of Belgium and The Netherlands as a function of late Weichselian morphology, relative sealevel rise and sediment supply. Neth J Geosci 79:3-16

Bindoff NL, Willebrand J, Artale V, Cazenave A, Gregory J, Gulev S, Hanawa K, Le Quéré C, Levitus S, Nojiri Y, Shum CK, Talley LD, Unnikrishnan A (2007) Observations: oceanic climate change and sea level. In: Solomon S, Qin D, Manning M, Chen Z, Marquis M, Averyt KB, Tignor M, Miller HL (eds) Climate Change 2007: the physical science basis. Contribution of Working Group I to the Fourth Assessment Report of the Intergovernmental Panel on Climate Change. Cambridge University Press, Cambridge, pp 385-532

Coastal Engineering Manual (2002) Erosion, transport and deposition of cohesive sediments. US Army Corps of Engineers, EM 11102-1100, part III, chap 5

Dawson AG, Hickey K, Holt T, Elliott L, Dawson S, Foster IDL, Wadhams P, Jonsdottir I, Wilkinson J, McKenna J, Davis NR, Smith DE (2002) Complex North Atlantic Oscillation (NAO) index signal of historic North Atlantic storm-track changes. Holocene 12:363-369

de Jong F, Bakker JF, van Berkel CJM, Dankers NMJA, Dahl K, Gätje C, Marencic H, Potel P (1999) Wadden Sea quality status report. Wadden Sea Ecosystem no 9. Trilateral monitoring and assessment group, quality status report group, Common Wadden Sea Secretariat, Wilhelmshaven, Germany

Delafontaine MT, Flemming BW (2000) The Wadden Sea squeeze as a cause of decreasing organic loading. In: Flemming BW, Delafontaine MT, Liebezeit G (eds) Muddy coast dynamics and resource management. Proceedings in Marine Science, vol 2. Elsevier, Amsterdam, pp 273-286

Du Four I, Van Lancker V (2008) Changes of sedimentological patters and morphological features due to the disposal of dredge spoil and the regeneration after cessation of the disposal activities. Mar Geol 255:15-29

Fettweis M, Van den Eynde D (2003) The mud deposits and the high turbidity in the Belgian-Dutch coastal zone, Southern Bight of the North Sea. Cont Shelf Res 23:669-691

Fettweis M, Nechad B, Van den Eynde D (2007a) An estimate of the suspended particulate matter (SPM) transport in the southern North Sea using SeaWiFS images, in-situ measurements and numerical model results. Cont Shelf Res 27:1568-1583

Fettweis M, Du Four I, Zeelmaekers E, Baeteman C, Francken F, Houziaux J-S, Mathys M, Nechad B, Pison V, Vandenberghe N, Van den Eynde D, Van Lancker V, Wartel S (2007b) Mud Origin, Characterisation and Human Activities (MOCHA). Belgian Science Policy EV/35. http://www.belspo.be/belspo/home/publ/ pub_ostc/EV/rappEV35_en.pdf

Flemming BW (2002) Effects of climate and human interventions on the evolution of the Wadden Sea depositional system (southern North Sea). In: Wefer G, Berger W, Behrke K-E, Jansen E (eds) Climate development and history of the North Atlantic realm. Springer, Berlin, pp 399-413

Gilson G (1900) Exploration de la mer sur les côtes de la Belgique en 1899. Mem Musée R Hist Nat Belg I

Gilson G (1901) A new sounding and ground collecting apparatus. BAAS 71:696-697

Hamilton LJ (1999) Classification, grainsize relations and sediment distributions inferred from visual sediment descriptions on RAN Hydrographic Office bathymetry charts of the northern Great Barrier Reef lagoon. Aust J Earth Sci 46:501-514
Holgate SJ, Woodworth PL (2004) Evidence for enhanced coastal sea level rise during the 1990s. Geophys Res Lett 31:L07305. doi:10.1029/2004GL019626

Houziaux J-S, Kerckhof F, Degrendele K, Roche M, Norro A (2008) The Hinder banks: yet an important region for the Belgian marine biodiversity? Belgian Science Policy EV/45. http://www.belspo. be/belspo/home/publ/pub_ostc/EV/rappEV45_en.pdf

Jaffe BE, Smith RE, Foxgrover AC (2007) Anthropogenic influence on sedimentation and intertidal mudflat change in San Pablo Bay, California: 1856-1983. Estuar Coastal Shelf Sci 73:175-187

Lacroix G, Ruddick K, Ozer J, Lancelot C (2004) Modelling the impact of the Scheldt and Rhine/Meuse plumes on the salinity distribution in Belgian waters (southern North Sea). J Sea Res 52:149-163

Lauwaert B, Bekaert K, Berteloot M, De Brauwer D, Fettweis M, Hillewaert H, Hoffman S, Hostens K, Mergaert K, Moulaert I, Parmentier K, Vanhoey G, Verstraeten J (2008) Synthesis report on the effects of dredged material disposal on the marine environment. MUMM, ILVO, AK \& AMT Rep, Brussels

Le Bot S, Van Lancker V, Deleu S, De Batist M, Henriet J-P (2003) Tertiary and Quaternary geology of the Belgian Continental Shelf. Belgian Science Policy SP1212. http://www.belspo.be/ belspo/home/publ/pub_ostc/Cpen/CP21Valo_en.pdf

Loewe P, Koslowski G (1994) The western Baltic sea ice season in terms of a mass-related severity index: 1879-1992. Part II. Spectral characteristics and associations with the NAO, QBO and solar cycle. Tellus 50A:219-241

Mai S, Bartholomä A (2000) The missing mud flats of the Wadden Sea: a reconstruction of sediments and accommodation space lost in the wake of land reclamation. In: Flemming BW, Delafontaine MT, Liebezeit G (eds) Muddy coast dynamics and resource management. Proceedings in Marine Science, vol 2. Elsevier, Amsterdam, pp 257-272

Maréchal R (1993) A new lithostratigraphic scale for the Palaeogene of Belgium. Bull Belg Ver Geol (Bull Soc Belg Géol) 102:215229

Missiaen T, Murphy S, Loncke L, Henriet J-P (2002) Very highresolution seismic mapping of shallow gas in the Belgian coastal zone. Cont Shelf Res 22:2291-2301

Ozer J, Van den Eynde D, Ponsar S (2008) Trend analysis of the relative mean sea level at Oostende (Southern North Sea-Belgian coast). Brussels, MUMM Rep CLIMAR/X/JO/200807/EN/TR3

Silva-Jacinto R, Le Hir P (2001) Response of stratified muddy beds to water waves. In: McAnally WH, Mehta AJ (eds) Coastal and estuarine fine sediment processes. Proceedings in Marine Science, vol 3. Elsevier, Amsterdam, pp 95-108

Smits A, Klein Tank SMG, Können GP (2005) Trends in storminess over The Netherlands 1962-2002. Int J Climatol 25:1331-1344

Stessels A (1866) Carte générale des bancs de Flandre compris entre Gravelines et l'embouchure de l'Escaut. Ministre des Affaires Etrangères, Anvers

Urbain (1909) Carte "Mer du Nord, Dunkerke - Flessingue". Royaume de Belgique, Service des Ponts et Chaussées Rep 687 (including updates from 11 May 1911)

Van Cauwenberghe C (1999) Relative sea level rise: analyses and conclusions with respect to the high water, the mean sea and the low water levels along the Belgian coast. Hydrographic Survey, Oostende, Belgium, Rep 46

Van den Eynde D, Fettweis M (2006) Modelling of fine-grained sediment transport and dredged material on the Belgian Continental Shelf. In: ICS 2004 Proc. J Coastal Res SI 39:1564-1569

Van den Eynde D, Francken F, Ponsar S, Ozer J (2008) Assessment of the primary impacts of climate change: statistical analysis of measurements of waves, of wind speed and direction and of sea water temperature. Brussels, MUMM Rep CLIMAR/X/DVDE/ 200807/NL/TR4 
Van Lancker V, Du Four I, Verfaillie E, Deleu S, Schelfaut K, Fettweis M, Van den Eynde D, Francken F, Monbaliu J, Giardino A, Portilla J, Lanckneus J, Moerkerke G, Degraer S (2007) Management, research and budgeting of aggregates in shelf seas related to endusers (Marebasse). Belgian Science Policy EV/18. http://www. belspo.be/belspo/home/publ/pub ostc/EV/rEV18 en.pdf

van Loen H, Houziaux J-S, Van Goethem J (2002) The collection Gilson as a reference framework for the Belgian marine fauna: a feasibility study. Belgian Science Policy MN/DD2/010. http:// www.belspo.be/belspo/home/publ/rappMNDD2 en.stm

Van Maldegem DC, Mulder HPJ, Langerak A (1993) A cohesive sediment balance for the Scheldt esuary. Neth J Aquat Ecol 27:247-256

Van Mierlo C-J (1897) Quelques mots sur le régime de la côte devant Heyst. Ann Assoc Ingénieurs Gand XX
Van Mierlo C-J (1899) La carte lithologique de la partie méridionale de la mer du Nord. Bull Soc Belg Géol XII:219-265

Van Mierlo C-J (1908) Le port de Heyst. Ann Assoc Ingénieurs Gand 4è série I 3

WASA Group (1998) Changing waves and storms in the Northeast Atlantic? Bull Am Meteorol Soc 79:741-760

Weisse R, Von Storch H, Feser F (2005) Northeast Atlantic and North Sea storminess as simulated by a regional climate model during 1958-2001 and comparison with observations. J Climate 18:465-479

Zviely D, Kit E, Rosen B, Galili E, Klein M (2009) Shoreline migration and beach-nearshore sand balance over the last 200 years in Haifa Bay (SE Mediterranean). Geo-Mar Lett 29:93-110. doi:10.1007/s000367-008-0126-2 